\title{
Synergy of Microtechnology and Biotechnology: Microreactors as an Effective Tool for Biotransformation Processes ${ }^{\S}$
}

\section{Anita Šalić and Bruno Zelić*}

University of Zagreb, Faculty of Chemical Engineering and Technology, Marulićev trg 19, HR-10000 Zagreb, Croatia

Received: 19 January 2018 Accepted: 4 September 2018
*Corresponding author:

Phone: +38514597104,+38514597281; Fax: +38514597133;

E-mail: bzelic@fkit.hr

ORCID IDs: 0000-0002-4808-363X (Šalić), 0000-0003-3210-2960 (Zelić)

${ }^{\S}$ The paper was presented at European Biotechnology Congress, 25-27 May 2017, Dubrovnik, Croatia

\section{SUMMARY}

Despite the fact that microreactors have been present for more than 40 years now and that their potential has been extensively exploited in chemical synthesis, analytics and screening, to date very few biocatalytic processes have been explored in microreactors. It is claimed that enzymatic microreactor technology is exactly in the same place where chemical microreactors were 15 years ago. However, general opinion is that the efforts devoted to the research of micro-enzymatic reactors will inaugurate a new breakthrough in bio-based processing. The aim of this review is to explore the synergy between microtechnology, mainly microreactors, and biotechnology, and to assess its potential, opportunities, challenges and future application in biotechnology.

Key words: microreactor, biotechnology, enzyme, immobilization, biocatalysis

\section{INTRODUCTION}

One of the leading researchers in the field of microreactor technology, Volker Hessel (1), said: 'Innovations are fragile. What is called first vision easily turns to an illusion. Illusions have the moment of disorientation. That leads to disillusion. The fate of not overcoming that is clear. Frustration comes if high promises turn into dissatisfaction. If surviving, the status of an innovation has been reached.' The first vison, the first fragile innovation of the microreactor technology emerged some 40 years ago (in 1977) and it took nearly two decades for the innovation 'to survive'. The mid-1990s are usually considered the beginning of the era of microreactor technology $(2,3)$, which has been growing almost exponentially ever since. Although many will agree that this is a new technology, especially in comparison to traditional technologies like batch, tubular reactor systems, etc., some might raise a justified question: Is the idea behind microreactor really a new one? A cursory glance at nature, at nutrient transport in leaves, oxygen/carbon dioxide exchange in million alveoli, the capillary system in the body, etc. will reveal that 'microreactors' have been present all around us for millions of years now. And if nature always finds the best way, how come that it took so many years for this idea/concept/technology to find its application in everyday science/production? According to Whitesides (4), a new technology needs 10-20 years to develop, amounting to the costs as high as $\$ 100+$ million. The underlying reason behind this is probably hidden in the general definition of microreactor technology: 'Microreactors are defined as miniaturized reaction systems fabricated by using, at least partially, methods of microtechnology and precision engineering' (5). Microtechnology and precision engineering, at the base of this technology, are the methods that became generally available in the mid-1990s. They finally allowed the development of reactor systems with small internal dimensions or diameters (on a scale from 10 to $500 \mu \mathrm{m}$ ) etched into a solid support.

From a retrospective point of view, a microreactor technology as an innovation has obviously survived simply by meeting the rule of thumb needs of a new technology: 'Being a new technology that has to fit into an existing laboratory set-up, it is essential that lab-on-chip equipment is compatible with the pre-existing robotics and automation lay-out of the lab' (1). Nowadays, microreactors have a strong presence in science and some industries, which raises the following questions: Does something that had a bumpy start in the first 20 years, and 
a revival in the next 20 years, may have a bright future in the forthcoming 20 years? Is microreactor technology currently at its peak or does it still have a great potential for growth? In line with the publications (6), patents (more precisely, according to European Patent Office (EPO) Worldwide Patent Statistical Database (7), approx. 1639 patents concern microreactors) and industry development, a simple answer would be: Yes, it does.

On the contrary, in the context of microreactor technology, one should always have in mind that a majority of research studies, patents and the progress achieved, from those early days until today, make a reference to chemical microreactors which, according to Jensen (8), have matured and come of age. In contrast, only a small percentage accounts for microreactors used in other areas. Biotechnology is still one of the underexplored areas (from the microreactors' point of view). So far, only a few enzymes have been applied in the microreactor-based process development and only a few patents ( 13 patents associated with microbioreactors according to the EPO (7) or a merely $0.79 \%$ of the total number of microreactor patents) describing such reactors have been reported. All of this indicates that this area is in its initial phase (1). The question this paper will try to address is as follows: Is biotechnology the next area of expansion and the future of microreactor technology?

\section{MICROREACTORS - A SHORT OVERVIEW}

As mentioned above, microreactors utilize small internal dimensions or diameters (on a scale from 10 to $500 \mu \mathrm{m}$ ) to manipulate and control fluids in a controlled environment (9). They can be divided into two classes: chip-type microreactors and microcapillary microreactors. The chip-type microreactors are most often used because they offer several advantages in comparison to the microcapillary type microreactors such as easy control and integration of multiple processes into a single reactor system (10). Microreactors can be produced from different materials such as glass, quartz, silicon, metals and polymers. The selection of the optimal material depends on its chemical compatibility with the reaction mixture, the costs and the analytical methods used in process monitoring and control. Glass is the most commonly used material since it is chemically inert and transparent, allowing its users visual observation of microchannels $(11,12)$. Microchannels are produced by different methods, including: powder blasting, wet etching, laser drilling, dispensing, photolithography, etc. $(13,14)$. According to the production methods, different types of surface roughness can be achieved in the microchannel. Surface roughness of the channel walls is speculated to be one of the most important factors because a reduction in the channel dimension increases the impact of roughness on the reaction. The average channel roughness is usually between 0.8 and $2.5 \mu \mathrm{m}$, depending on the selected microchannel manufacturing process.

The most common and simplest microchannel type is the so-called tubular microchannel: a simple, straight or curved tube etched onto a microchip. In order to enhance mixing and separation, different structures can be incorporated as part of the microchannel: micromixers (i.e. teardrop or swirl $(15,16))$, zigzag flow obstacles (17), nozzle injections, etc. By simple manipulation of inlet design, it is possible to obtain different flow patterns in a microchannel. The most common inlet designs are $\mathrm{Y}$-, T- and $\psi$ - (Fig. 1).

Microchannel is a basic structure of a microreactor system with some additional parts needed for its functionality. One of them is solid base material on which microchannel is positioned (microchannel and base together form a chip) and connecting fluid lines that, together with the chip, form a microreactor unit (Fig. 1).

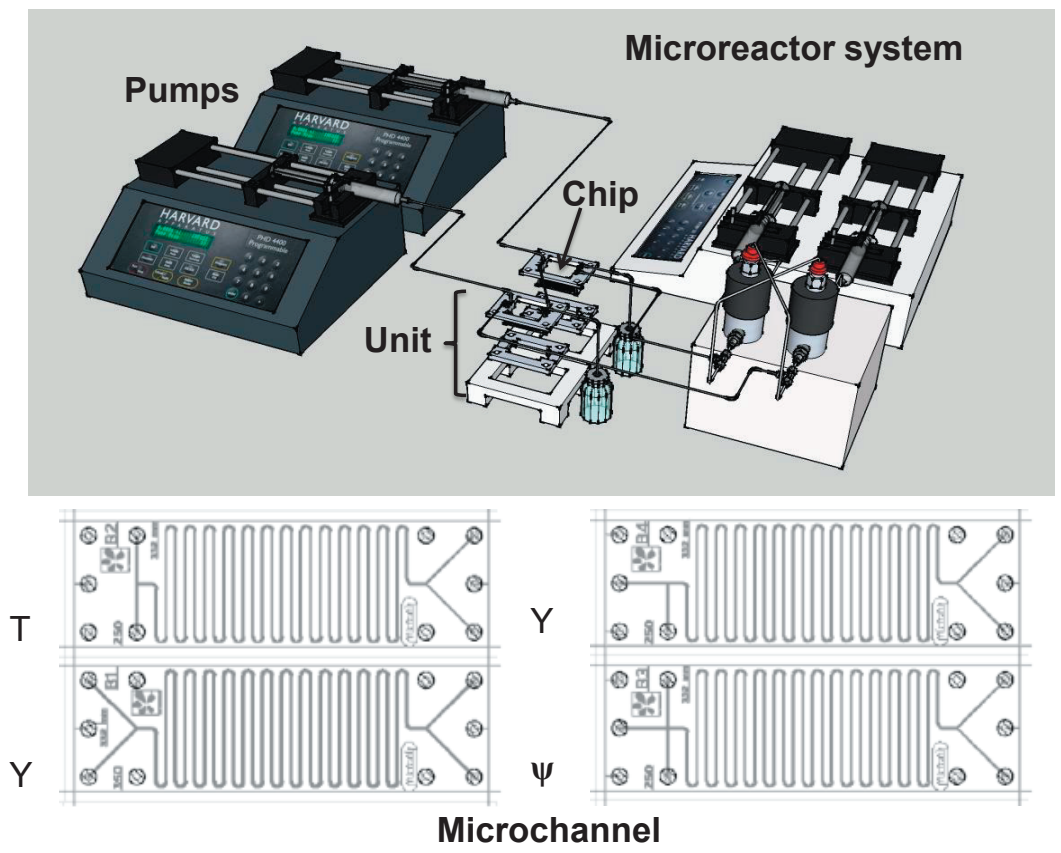

Fig. 1. Basic structure unit of microreactor system together with microchannels with different inlet shapes 
Biochemical processes and biotechnology itself are never simple. The utilization of multiple enzymes, parallel reactions, product separation, etc. requires more complex devices. A combination of different processes in a single microchip is one of the current research aims in the field of microtechnology. Such devices, the so-called micro total analysis systems ( $\mu \mathrm{TAS}$ ), can perform integrated sampling, sample preparation, detection and data processing in a single chip. The most common use of $\mu$ TAS is in research in the biomedical field (i.e. DNA analysis and proteomics) (12).

\section{Why are microreactors a good choice?}

There are many benefits offered by simply shrinking the reactor size. On a smaller scale a lot of new physical phenomena can be observed and utilized as a positive trigger for many reactions. The most characteristic properties of microreactors can be divided into the following groups $(5,18)$ :

\section{Fast mixing and mass transfer}

Any reduction in microchannel dimensions reduces diffusion limitations of the enzyme and substrates, and mixing takes place by molecular diffusion. Therefore, a concentration gradient can be avoided. This is especially important for the reaction systems in which active site of the enzyme and the substrate are very distant. Exploiting the benefits of reduced microchannel size, limitations of the effective reaction rate can be avoided (19). Also, microreactors can be used for the enzyme kinetic characterisation and molecule screenings (20). Kinetics is especially important for the development of the enzyme-catalysed reactions in large-scale productions as well as in the use of microreactors. The knowledge of enzyme kinetics is essential in order to find the optimal process conditions and facilitate identification of the most effective mode of process operation (21). Tadepalli et al. (22) claim that an estimation of kinetics of fast reactions in a microreactor would give more precise results because the mass transfer effects prevail over intrinsic kinetics in fast reactions performed in a macroscopic reactor. For that reason, mass transfer limitations that impede the true kinetics pose a problem that can be solved in a microreactor (23). The same effect is noticed in two-phase systems in which the phases are immiscible, i.e. organic-water system, in which the kinetic measurements performed in a cuvette (a traditional approach to kinetic parameter estimation) are strongly influenced by insufficient mixing due to its geometry and the properties of different phases constituting the two-phase system. Consequently, for kinetic measurements performed in a cuvette the kinetic measurements in the organic-water system result in the estimation of apparent kinetic parameters. Similar to fast reactions, the use of microreactors for kinetic measurements of the two-phase systems is the best way to estimate the true kinetic rates (23).

High surface-to-volume ratio

Specific surfaces of the microchannel (from 10000 to $50000 \mathrm{~m}^{2} / \mathrm{m}^{3}$ ) are significantly higher than those of traditional macroreactor systems (usually around 100 and $1000 \mathrm{~m}^{2} / \mathrm{m}^{3}$ ) (5), which as a consequence have a great effect on mass, momentum and energy transfer in the system. In biotechnology, besides the influence on mass transfer and its benefits explained previously, this is important for reactions performed by enzymes whose activity depends on the temperature. Due to high surface-to-volume ratio, heat transfer is very efficient, making it possible to regulate reaction temperatures in the system by very effective heat removal (24).

\section{Laminar flow}

This type of flow (a flow with low Reynolds numbers) favours control and modelling of a reaction. Since modelling of biotransformations is usually complex, the assumption of laminar flow as a base for model development can make the whole process much simpler. The laminar flow also provides high surface-to-volume ratio and interface areas, which is especially important for multiphase systems, whereas the laminar flow regime can result in diffusion-controlled reactions of compounds at the interface of two fluid streams (25). Additionally, it helps to eliminate any back-mixing in the system that may be caused by fluid turbulence (9).

\section{Small substrate volume}

When working with small reactor volumes, significant cost savings can be made in terms of the amount of substrates or biocatalysts used and needed for the reaction. This is particularly important in reactions in which purified or multiple enzymes are used as a biocatalyst since the price of enzymes can be extremely high. Microreactors also allow high repeatability of biocatalytic processes (20), so a lot of information about the process can be gathered with relatively small inlet volumes $(26,27)$, which is rarely the case with traditional reactor systems.

\section{Environmentally friendly}

As a follow-up of the above-mentioned advantage, if there is a small inlet of substrates, there has to be a small outlet of products and byproducts. And if combined with high productivity and conversion rates in microreactors, this system generates a reduction in the waste stream and the total amount of waste, which makes it environmentally friendly. Additionally, as mentioned previously, due to the microchannel high surface-to-volume ratio, heat transfer is very efficient, leading to extremely small energy consumption, resulting in environmental benefits (28).

\section{Safe reaction conditions}

Microreactors are considered safer than traditional reactors for reactions performed under extreme or dangerous conditions like high pressures, explosive or reactive reactants, high temperatures, etc. due to small volumes, extensive heat transfer and versatility of materials used for their production that can be easily adapted to any conditions (29-31). In contrast, the 
reactions performed in the field of biotechnology are mostly performed under mild $\mathrm{pH}$, temperature and pressure conditions, which does not represent a crucial advantage of microreactors but, as above-mentioned, if needed, microreactors can be easily adapted.

\section{Selectivity}

The literature suggests that many biological and chemical reactions improve three very important principles when the processes are performed in microreactors in comparison to traditional production practice: reactivity, productivity and selectivity (32). Namely, the reactions performed in microreactors generally result in purer products in shorter residence time than the equivalent reactions performed in traditional systems. This is because in reactions in which multiple products can be generated from a given set of reagents, depending on the local reaction conditions, the reaction can be shifted in a desirable direction. Since the use of microreactors, in comparison to conventional reactors, facilitates easy changes of reaction conditions, such as temperature or residence time, individual compounds among the multiple compounds can be produced with high degrees of precision (33).

\section{Rapid reactions}

Although researchers working in the field of microtechnology will often highlight that the reactions in microreactors are faster and generate higher space-time yields/productivities $(34,35)$, some other researches will challenge this statement. Elvira et al. (9) claim that there are a few fundamental things limiting the ability to make a direct comparison between the micro- and the macrosystem regarding their reaction speed. Bulk reactions are often performed with more time than would be necessary to reach the equilibrium point of the reaction in order to ensure that the desired reaction has reached its completion. Microreactors, on the other hand, are more easily optimized and closely monitored to avoid running for any longer than is necessary to reach the reaction endpoint, and are accordingly reported to have greater space-time yields/productivity than bulk reactors (35). Thus, even if the rate of rate-limited reactions is unchanged, microfluidic reactors will allow more efficient and consequently more rapid processes. On the contrary, the rate of mass-limited reactions will be increased for small characteristic dimensions of microreactors due to the significance the diffusive effects have in this domain, and consequently will have the same or greater effect of increasing process speeds (36).

\section{Numbering-up}

Numbering-up or scale-out is probably one of the major microreactor benefits and a topic of in-depth industrial analysis performed for process intensification (37). Like a LEGO system, complex but compact microfactories can be constructed simply by connecting microreactors to operate in parallel or in a series $(38,39)$. Uninterrupted continuous operation is the second biggest advantage of numbering-up, because if one of the units is broken, it can be easily replaced without affecting the other units. Also, complete pathway from development to production, passing all necessary steps like development time, testing and turnaround, is quite shorter than in the traditional scale-up (12). Yet another advantage comes from the fact that by using multiple reactors of the same size, the chemistry performed in each one remains the same at any level of scaling out (40). This approach allows easy transfer between research and industrial applications as well (41).

\section{BIOTECHNOLOGY ON A SMALL SCALE}

As mentioned in the introduction, to date very few enzymes have been applied in the microreactor-based process development, and the construction of enzymatic microreactors has been rarely described (42). This suggests that the application of microreactors in the bio-based process development is still in its initial stage. Hessel et al. (1) argue that the enzymatic microreactor technology is exactly in the same place where chemical microreactors were 15 years ago. However, general opinion is that the efforts focused on the development, optimization, and application of microenzymatic reactors will inaugurate a new era in bio-based economy (6,43-45).

When talking about enzymatic microreactors, their application can be roughly divided into two branches - one is referring to biotransformation processes and the other to molecule screenings and kinetic parameter estimations (20). Enzymes, as key elements in biotransformations, can be used in dissolved or immobilized form. Immobilized enzymatic reactors can be constructed by different approaches but usually covalent immobilization, adsorption or co-polymerization is applied (46).

In the following section, an overview of some relevant research studies performed by using enzymatic microreactors will be given in order to validate all the above-mentioned advantages of microreactor technology.

\section{The simplest form: one chip - one enzyme}

Although the title contains the word 'simple', there is usually nothing simple in transferring processes from batch to the flow mode of operation. The complete approach includes a lot of preliminary research studies like defining residence time, flow regime, inlet concentrations, stream content, choice of best microreactor type, etc. After all the initial conditions have been identified, one can hope that biotransformation will be successful. In this context 'simple' mostly refers to the mere application of microreactors in which selected continuous flow reactions are performed on a single commercially manufactured microchip. In order to start the reaction, reactant(s) and catalyst have to be introduced separately into the reactor, typically by high-pressure syringe pumps, and then a continuous flow forms the reaction mixture through the microchannel (47). 
An example of this simple approach is the work of Jurinjak Tušek et al. (48) where the authors performed enzymatic oxidation of phenolic compounds, catechol and L-DOPA using commercial laccase from Trametes versicolor in a two-aqueous-phase microflow microreactor. A catechol conversion rate of $41 \%$ and a L-DOPA conversion rate of $45 \%$ were obtained in $\tau=72 \mathrm{~s}$, respectively. The efficiency of the proposed microreactor system was confirmed by comparing the oxidation rates. In the case of catechol oxidation, the oxidation rates were 18-167 fold higher than in the same reaction performed in a macroreactor. Kinetic investigations showed that the maximum reaction rate achieved in the microflow system was two times higher than the one obtained for the synthesis in a cuvette. As mentioned above, any reduction in microchannel dimensions reduces the diffusion limitations of the enzyme and substrates as well as product transfer, which significantly affects the effective reaction rate $(49,50)$.

Another example is enzymatic oxidation of hexanol to hexanal (a green note fragrance) using $\mathrm{NAD}^{+}$-dependent commercial alcohol dehydrogenase from Saccharomyces cerevisiae $(23,51,52)$. In these research studies, biotransformation was performed in four different tubular microreactors (different internal volumes of microreactors with or without the presence of micromixers, as well with two different surface types: rough channel with a relative channel roughness around 10 $\%$ and a smooth one with roughness around $1 \%$ ) (Fig. 2). The impact of different process parameters on the conversion and volumetric productivity was studied as a measure of process efficiency. It was observed that in the $6-\mathrm{mm}^{3}$ tubular microreactor, $30 \%$ conversion rate of hexanol was achieved after $36 \mathrm{~s}$, while in a macroreactor $5.3 \%$ conversion rate of hexanol was obtained after $180 \mathrm{~s}$ (53), showing a significant progress.

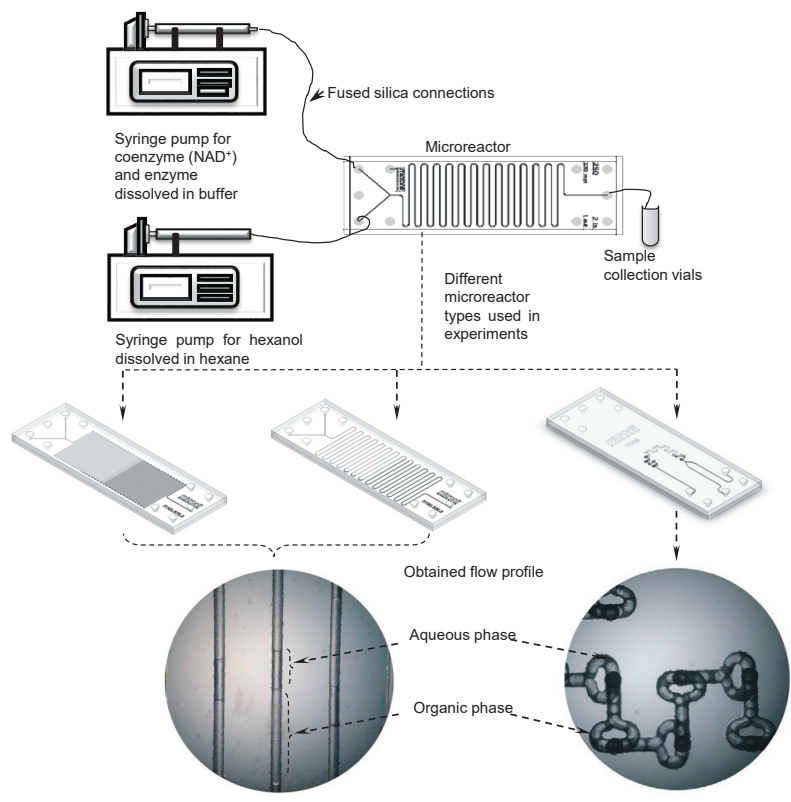

Fig. 2. Schematic diagram of the reaction system used for the hexanal biotransformation together with the obtained flow profiles
When comparing smooth and rough microchannel walls of the same reaction system for the same residence time, the conversion rate was 2 -fold higher in the smooth than in the rough wall. Namely, the mass transfer occurs at the interface area between the phases (54). When both surface areas were calculated, it was noticed that the microreactor with smooth walls had a larger interface area (around $1.66 \cdot 10^{-5} \mathrm{~m}^{2}$ ) for the same residence time than the microreactor with rough walls, leading to higher conversion rates. Another advantage of a microreactor with smooth walls was a formation of parallel and stabile fluid flow from the microchannel inlet to its outlet, which allowed separation of organic and aqueous phases leading to the development of the integrated system.

The kinetic measurement was also performed for the same reaction system (23). The enzyme kinetics was described as a pseudo-homogeneous process with the double substrate Michaelis-Menten rate equation. The measurements showed that the calculated reaction rate was 30 -fold higher in the microreactor than in the cuvette. No significant difference was noticed among all the other Michaelis-Menten constants (53). No product inhibition was estimated in microreactor kinetic experiments, which was not the case for kinetic measurements performed in a macrosystem. This finding could be explained by hydrodynamic effects and the continuous removal of inhibiting products occurring in microreactors. Table 1 (55-64) includes a list of some examples of biotransformation in microreactors by use of free enzymes.

Another problem associated with enzymes is their use in purified form. Purified enzymes are usually expensive due to many steps that are necessary for their purification. As an alternative, partially purified enzymes and crude cell lysates could be used $(65,66)$. The advantages of crude cell lysates in comparison to isolated enzymes are lower costs, since extraction and purification of enzymes are avoided. Also, due to their size they are easier to recycle and enzymes are much more stabile if they are in their natural intracellular environment (67). When talking about limitations, mass transfer is one of them (68) since molecules (substrate, co-substrate, and product) have to pass through the cell membrane to achieve contact with the enzyme. To overcome this obstacle, membrane can be permeabilized by using different organic solvents, mechanical procedures or electroporation (69). Additional limitation refers to specific activity that is lower than of pure enzymes.

To investigate the application of whole cells for biotransformation in a microreactor (Fig. 3a), a study of coenzyme NAD ${ }^{+}$ regeneration was carried out by acetaldehyde reduction to ethanol using suspended permeabilized baker's yeast cells as a source of enzyme alcohol dehydrogenase (ADH) (70). Conversion rate of $\mathrm{NADH}$ was $65.3 \%$ in a residence time of just $\tau=36 \mathrm{~s}$.

In addition to the above-mentioned disadvantages of the whole cell application, resulting from many different enzymes present in the cell, there is another disadvantage: multiple reactions leading to multiple products of which one is usually desired and the others are byproducts. The example is the reaction of hexanol oxidation using whole permeabilized yeast cells 
Table 1. Enzymatic biotransformations in microreactors using free enzymes

\begin{tabular}{|c|c|c|c|}
\hline Biotransformation & System & Process description & Reference \\
\hline Lipase-catalysed synthesis of isoamyl acetate & ionic liquid-organic solvent & $\begin{array}{l}\text { almost threefold better productivity than in the } \\
\text { intensely mixed batch process }\end{array}$ & $(55)$ \\
\hline Laccase-catalysed L-DOPA oxidation & two aqueous phases & $\begin{array}{l}87 \% \text { conversion reached in residence time under } \\
2 \mathrm{~min}\end{array}$ & (56) \\
\hline $\begin{array}{l}\text { Esterification of isoamyl alcohol and acetic } \\
\text { acid using Candida antartica lipase B }\end{array}$ & $\begin{array}{l}\text { aqueous phase-organic } \\
\text { solvent }\end{array}$ & $\begin{array}{l}35 \% \text { conversion reached in residence time of } \\
36.5 \mathrm{~s}\end{array}$ & $(57)$ \\
\hline $\begin{array}{l}\text { Enzymatic oxidation of cholesterol to } \\
\text { 4-cholesten-3-one by cholesterol oxidase }\end{array}$ & $\begin{array}{l}\text { aqueous phase-organic } \\
\text { solvent }\end{array}$ & $\begin{array}{l}70 \% \text { conversion reached in residence time less } \\
\text { than } 1 \mathrm{~min}\end{array}$ & $(58)$ \\
\hline $\begin{array}{l}\text { Phenolic compound oxidation using } \\
\text { horseradish peroxidase }\end{array}$ & aqueous phase & $\begin{array}{l}\text { 1.5-fold higher conversion reached using enzyme } \\
\text { immobilized in monolayer than using physical } \\
\text { adsorption processes }\end{array}$ & (59) \\
\hline $\begin{array}{l}\text { Hydrolysis of soybean oil catalysed by } \\
\text { Thermomyces lamuginosus lipase }\end{array}$ & $\begin{array}{l}\text { aqueous phase-oil } \\
\text { emulsion }\end{array}$ & $\begin{array}{l}25-30 \% \text { conversion reached in the residence time } \\
\text { of } 10 \mathrm{~min}\end{array}$ & $(60)$ \\
\hline $\begin{array}{l}\text { Transketolase-catalysed reaction of } \\
\text { hydroxypyruvate and glycolaldehyde to } \\
\text { L-erythrulose }\end{array}$ & two aqueous phases & $\begin{array}{l}100 \% \text { conversion reached in the residence time } \\
\text { of } 60 \mathrm{~min}\end{array}$ & (61) \\
\hline $\begin{array}{l}\text { Alcohol dehydrogenase from Saccharomyces } \\
\text { cerevisiae catalysed } \mathrm{NADH}^{+} \text {coenzyme } \\
\text { regeneration }\end{array}$ & two aqueous phases & $\begin{array}{l}95.89 \% \text { conversion reached in the residence time } \\
\text { of } 2 \mathrm{~s}\end{array}$ & $(62)$ \\
\hline $\begin{array}{l}\text { Aldol addition of dihydroxyaceton to N-Cbz-3- } \\
\text {-aminopropanal catalysed by two D-fructose-6- } \\
\text {-phosphate aldolase variants was preformed }\end{array}$ & $\begin{array}{l}\text { aqueous phase-organic } \\
\text { solvent }\end{array}$ & $\begin{array}{l}\text { more than threefold higher volume productivity } \\
\text { achieved in microreactor with micromixers than in } \\
\text { batch process }\end{array}$ & (63) \\
\hline $\begin{array}{l}\text { Synthesis of (S)-2-hydroxypropiophenone ((S)- } \\
\text {-2-HPP) from benzaldehyde and acetaldehyde } \\
\text { catalysed by benzoylformate decarboxylase } \\
\text { (BFD) from Pseudomonas putida }\end{array}$ & $\begin{array}{l}\text { aqueous phase-organic } \\
\text { solvent }\end{array}$ & $\begin{array}{l}\text { all microreactors showed } 72 \text {-fold higher volume } \\
\text { productivity }\end{array}$ & (64) \\
\hline
\end{tabular}

in which the target molecule is hexanal but due to many other enzymes present in the cell, hexanoic acid is also produced (71).

Since a free enzyme is used in the most of the foregoing processes, the problem how to separate the reaction mixture components (mainly the enzyme and the product) in the final step is one of the key and most important aspects of microreactor technology. There are two reasons for this. Firstly, it makes product purification easier, and secondly, a failure to separate the enzyme, which is usually the most expensive component of the reaction mixture, leads to its continuous loss. As mentioned above, by choosing the right microchannel it is possible to obtain an efficient phase separation since one of the microreactor advantages is formation of the stable, uninterrupted, laminar flow from the microreactor inlet to its outlet. On the contrary, if that is not the case, the microchannel surface can be easily modified (usually by some chemical methods) to have certain desired properties (i.e. to become hydrophobic or hydrophilic). That approach was implemented in the work carried out by Maruyama et al. (72) in which the surface of a glass microchannel was modified by octadecylsilane groups to obtain a hydrophobic surface. This modification allows efficient phase separation at the outlet junction of the microchannel. Phenolic compound ( $p$-chlorophenol) was then successfully degraded using enzyme laccase in a two-phase flow in a glass microreactor and almost $75 \%$ of phenolic compound was degraded at the flow velocity of $0.1 \mathrm{~cm}^{3} / \mathrm{h}$.

If this approach (utilizing advantages of the microreactor properties) is not suitable, and if the enzyme cannot be recovered and reused after the reaction, then enzyme immobilization is applied as another approach.

\section{One step further: enzyme immobilization}

Immobilized enzymes are especially important from commercial production point of view. The use of immobilized enzymes results in reduced operational costs and increased overall enzyme utilization. Besides economic benefits, immobilization is used to enhance enzyme stability, meaning immobilized enzymes usually have better thermal and operational stability at different process conditions. They are commonly longer resistant to denaturation, more stable during storage, and what is especially important, they enable good enzyme and product separation with the possibility of further enzyme reuse $(73,74)$. Nowadays, researchers are focused not only on enzyme immobilization techniques, but also on the development of different enzyme carriers that could be used in continuous processes aiming to lower the overall production costs (75). Some general requirements for immobilization include stability under fluid flow and reversibility on demand, implying that the inactive enzyme can be relatively easily replaced by an active one (76). Immobilization should also provide a high binding capacity resulting in a sufficient amount of enzyme attached onto the surface area that is available internally. For the ideal process system, immobilization should be highly selective, thus allowing the target enzyme to be captured from a complex protein mixture without any protein purification and separation prior to immobilization (76).

Enzyme immobilization techniques are especially important because the immobilization efficiency significantly depends on the immobilization method that is applied. The implemented methods can largely be categorised as adsorption, 
cross-linking, affinity, covalent immobilization, or entrapment $(42,77)$

Generally, the most typically applied method is covalent immobilization (surface silanization followed by glutaraldehyde bonding - three-step immobilization) on solid support like beads, membrane, microreactor surface, etc. The main advantage is formation of a strong enzyme-surface link, which has several advantages like durability and longevity of immobilized enzymes. This is important since it prevents enzyme detachment and leaching from the microreactor. The second advantage is related to the enzyme structure. Immobilization introduces additional multipoint attachment, which makes the tertiary structure of the enzyme more stable and resistant to refolding (78). On the other hand, formation of additional attachments can affect the active site deformation, leading to lower activity. That is why, prior to immobilization, it is essential to obtain information about protein conformation in order to ensure proper immobilization method (79).

While coupling by glutaraldehyde is common, the method itself is not really exciting and new. In fact, while still used by some, more and more researchers are exploring different approaches. The main idea behind these new methods is to simplify immobilization procedure, meaning to develop the immobilization system that will work in one step (one-step immobilization). The process would include parallel enzyme production and selective attachment of desired enzyme (80).

One of the proposed immobilization techniques that could be used for this purpose is polycationic binding tag/moduls such as $Z_{\text {basic2. }}$. The idea behind this approach is to induce interactions between positively charged tags (like $Z_{\text {basic } 2}$ ) and negatively charged microchannel walls. The enzyme itself is previously fused with modules. Recently, several research groups have investigated this approach on a microscale. Miložič et al. (81) fused protein N-SBM-ATA-wt consisting of selected $\omega$-transaminase ATA-wt and the $Z_{\text {basic }}$ tag in order to demonstrate the usefulness of time scale analysis. The same group, using the same enzyme, made a comparison between different immobilization techniques comparing the covalent immobilization (surface silanization followed by glutaraldehyde bonding - three-step immobilization), the use of fused $\mathrm{N}$-SBM-ATA-wt complex (one-step method) and covalent E. coli cell overexpressing ATA-wt immobilization. Comparing the results, fused complex gave overall better results, meaning higher enzyme loading and productivity than covalent enzyme immobilization (82). Valikhani et al. (83) managed to obtain two-fold higher enzyme effectiveness by combining the enzyme and the mentioned module. Bolivar et al. (80) managed to run a continuous 16-day process of 2-O-(a-D-glucopyranosyl)-sn-glycerol (aGG) (a natural osmolyte) production with operational half-life of about 10 days when enzyme sucrose phosphorylase was fused with $Z_{\text {basic2 }}$ module.

Another well-established method for one-step protein immobilization is the use of recombinant tags, especially polyhistidine tags (His-tags) (84). The method emerged from immobilized metal affinity chromatography (IMAC) and it has been widely used for protein immobilization $(85,86)$. It became popular because it allows protein immobilization prior to protein purification and it is fast, simple and highly specific. Using this approach, Halim et al. (87) managed to synthesize a chiral amino alcohol (diastereoisomer of 2-amino-1,3,4-butanetriol (ABT)) by using two enzymes, transketolase (TK) and transaminase (TAm). They developed a microreactor loaded with Ni-NTA agarose beads that consisted of immobilized $\mathrm{His}_{6}$-tagged TK and TAm and managed to obtain approx. $83 \%$ conversion in the residence time of $20 \mathrm{~min}$. Poly(methyl methacrylate) (PMMA) microfluidic devices are especially interesting for forming His-tag enzyme interaction because PMMA surface does not require prior amination. For immobilization of TAm, this one-step immobilization method was compared to the three-step covalent immobilization. It was discovered that, despite the fact that by using the three-step method higher immobilization efficiency was achieved, enzyme-specific activity was better preserved by using one-step method (88).

Overall, based on the immobilization method, the enzyme, and the material used, microreactors with immobilized enzyme can be divided into several categories: (i) enzymes immobilized directly on the microchannel surface usually by a specific covalent immobilization method (Fig. 3b). The biggest disadvantage of this method is poor enzyme loading, but there is no additional back pressure formation (84); (ii) enzyme immobilized on the beads (known as bead activation process) in which beads are packed into the microreactor (i.e. immobilization on magnetic beads; Fig. 4). The biggest advantage is high load, and on the other hand, high back pressure is common disadvantage (89); (iii) enzyme immobilized on the monoliths in which meso- or macroporous monoliths are coated with a resistant layer or directly prepared in a microchannel and functionalised with enzymes. This approach minimizes previously mentioned disadvantages (44); and (iv) enzyme immobilized on the membranes in which enzymes are immobilized onto a selective ultrafiltration membrane (47).

Depending on the immobilization technique and choice of supporting material, different microreactor types are applied to achieve high enzyme load. Most common are membrane reactors, packed bed reactors (PBR), flow coils, coated-wall microreactors, etc. $(6,45)$. PBR is especially interesting when talking about biocatalysis with immobilized enzymes because it allows application on many versatile supports and immobilization techniques leading to many different applications. They can be used for screening (90), gradual scale-up study (91) or different biocatalytic reactions like transesterification (92) of vinyl butyrate and 1-butanol into butyl butyrate, amine synthesis (93) or valuable chemical synthesis like 2-amino-1,3,4-butanetriol (87).

Among these conventional reactors, microreactors with oscillating magnetic field started drawing attention. As mentioned before, one of the proposed immobilization methods is enzyme immobilization on the beads. Iron oxide magnetic nanoparticles (MNPs) have recently gained more attention in enzyme catalysis due to their multifunctional properties, such as 
a)

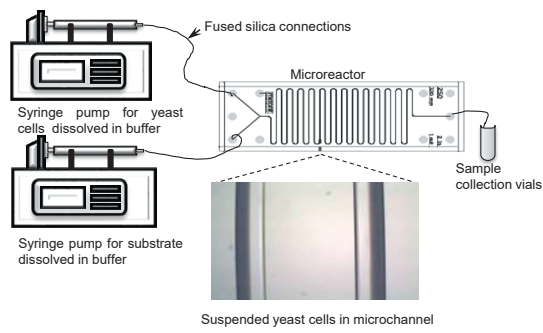

b)

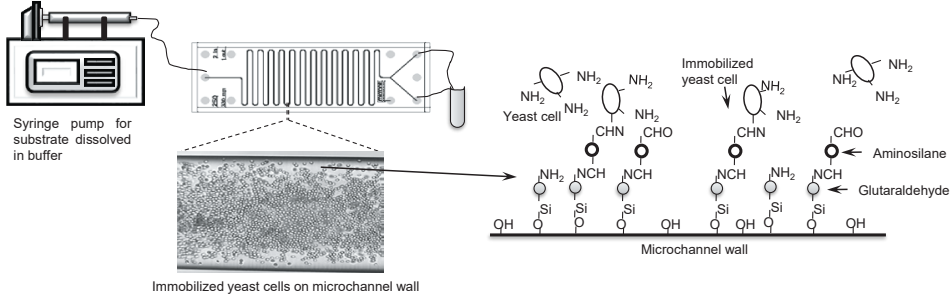

Fig. 3. Schematic diagram of the reaction system used for the coenzyme regeneration when: a) suspended and b) immobilized yeast cells were used together with proposed diagram for covalent immobilization of cells on the glass microchannel surface

biocompatibility, superparamagnetism, small size and low toxicity (94), high specific surface area and the separation is easy, simply by the use of a magnet $(95,96)$. Magnetite $\left(\mathrm{Fe}_{3} \mathrm{O}_{4}\right)$, maghemite $\left(\gamma-\mathrm{Fe}_{2} \mathrm{O}_{3}\right)$ and hematite $\left(\mathrm{a}-\mathrm{Fe}_{2} \mathrm{O}_{3}\right)$ are the most commonly used magnetic supports (97). When comparing maghemite and magnetite, some researchers like Kang et al. (98) highlight that maghemite has a greater binding specificity than magnetite nanoparticles. In addition to the above-mentioned MNP advantages, another advantage is that they can be easily handled in a microsystem.

For that purpose, Šalić et al. (99) proposed three different reactor systems in the process of NADH regeneration. Two of them were polytetrafluoroethylene (PTFE) tubes equipped with square and cylindrical permanent magnets, and the third was the PTFE tube equipped with an electromagnet with an oscillating magnetic field developed to enable magnetic particle movement in a microreactor (Fig. 4). The main difference between them was that the magnetic particles in both microreactor configurations, equipped with square and cylindrical permanent magnets, were placed on just one side of the reactor in several layers and the amount of the enzyme available to substrate was significantly decreased. Using an electromagnet with an oscillating magnetic field, it was possible to move actively or restrain the particles across the channel (Fig. 4). In this way the beads covered the whole channel cross-section making the enzyme more available to the substrate.

Table 2 provides a list of some additional examples of biotransformations using the enzyme immobilized in microreactors (70,71,74,90,100-107). Immobilized enzymes together with microfluidic devices have been applied in recent investigations for various reactions such as hydrolysis and esterification, C-C bond formation reaction, condensation and addition, oxidation and reduction, and polymerization reactions (42). Additional examples of enzyme immobilization in microreactors are extensively reviewed in the literature $(10,66,78,84,108-112)$.

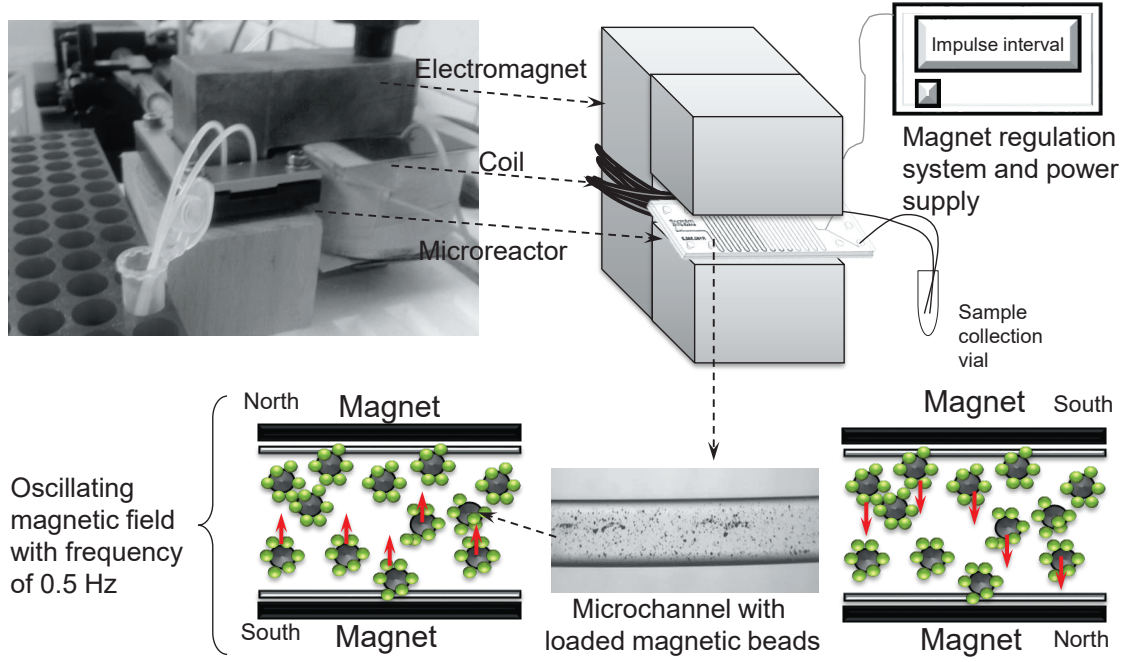

Fig. 4. Experimental set-up with a system for magnetic field regulation (99) 
Table 2. Enzymatic biotransformations in microreactors using immobilized enzyme

\begin{tabular}{|c|c|c|c|}
\hline Biotransformation & Method of enzyme immobilization & Process description & Reference \\
\hline $\begin{array}{l}\mathrm{NAD}^{+} \text {regeneration in } \\
\text { a microreactor using } \\
\text { permeabilized baker's } \\
\text { yeast cells }\end{array}$ & $\begin{array}{l}\text { covalently bound to the inner } \\
\text { surface of a microreactor by the } \\
\text { APTES/GA method }\end{array}$ & $\begin{array}{l}65.3 \% \text { conversion of NADH was achieved with suspended } \\
\text { permeabilized baker's yeast cells in a residence time of } \\
\tau=36 \mathrm{~s} \text { and equimolar concentration of substrates. When } \\
\text { working with immobilized cells, conversion achieved in } \\
\text { the same residence time was } 10 \text {-fold lower }\end{array}$ & $(70)$ \\
\hline $\begin{array}{l}\text { Hexanal and hexanoic acid } \\
\text { production using immobilized } \\
\text { ADH from Saccharomyces } \\
\text { cerevisiae }\end{array}$ & $\begin{array}{l}\text { covalently bound to the inner } \\
\text { surface of a microreactor by the } \\
\text { APTES/GA method-3 } \\
\text { immobilization methods tested }\end{array}$ & $\begin{array}{l}\text { maximal achieved conversion of hexanol was } 25 \% \text { in the } \\
\text { residence time of } 72 \mathrm{~s}\end{array}$ & $(71)$ \\
\hline $\begin{array}{l}\text { L-Malic acid production using } \\
\text { immobilized fumarase from } \\
\text { Saccharomyces cerevisiae }\end{array}$ & $\begin{array}{l}\text { covalently bound to the inner } \\
\text { surface of a microreactor by the } \\
\text { APTES/GA method }\end{array}$ & $80 \%$ conversion reached in the residence time of $8 \mathrm{~min}$ & $(74)$ \\
\hline $\begin{array}{l}\beta \text {-Glucosylglycerol synthesis } \\
\text { catalysed by immobilized } \\
\beta \text {-glycosidase CelB from } \\
\text { Pyrococcus furiosus }\end{array}$ & $\begin{array}{l}\text { covalently attached onto coated } \\
\text { microchannel walls }\end{array}$ & approx. $90 \%$ conversion reached in residence time of $10 \mathrm{~s}$ & $(100)$ \\
\hline $\begin{array}{l}\text { Synthesis of butyl laurate from } \\
\text { lauric acid and } n \text {-butanol using } \\
\text { immobilized lipase B from } \\
\text { Candida antartica }\end{array}$ & $\begin{array}{l}\text { lipase immobilization on the } \\
\text { amino activated silica fibre using } \\
\text { glutaraldehyde as a bifunctional } \\
\text { reagent }\end{array}$ & $\begin{array}{l}\text { approx. } 99 \% \text { yield reached in the residence time shorter } \\
\text { than } 38 \mathrm{~s}\end{array}$ & $(101)$ \\
\hline $\begin{array}{l}\text { Triolein transesterification } \\
\text { using immobilized lipase from } \\
\text { Pseudomonas fluorescens }\end{array}$ & $\begin{array}{l}\text { enzyme entrapped in matrix } \\
\text { membrane }\end{array}$ & $\begin{array}{l}\text { approx. } 80 \% \text { conversion reached in the residence time of } \\
19 \min \end{array}$ & $(102)$ \\
\hline $\begin{array}{l}\text { L-Malic acid production using } \\
\text { immobilized Saccharomyces } \\
\text { cerevisiae cells }\end{array}$ & $\begin{array}{l}\text { covalently bound to the inner } \\
\text { surface of a microreactor by the } \\
\text { APTES/GA method }\end{array}$ & $70 \%$ conversion reached in the residence time of $25 \mathrm{~min}$ & $(103)$ \\
\hline $\begin{array}{l}\text { The acylation of isoamyl } \\
\text { alcohol with acetic anhydride } \\
\text { catalysed by immobilized } \\
\text { Candida antartica lipase B }\end{array}$ & $\begin{array}{l}\text { covalently bound to the inner } \\
\text { surface of a microreactor by the } \\
\text { APTES/GA method }\end{array}$ & $92 \%$ yield reached in the residence time of $45 \mathrm{~min}$ & $(90)$ \\
\hline $\begin{array}{l}\text { Continuous synthesis of } \\
\text { lactulose catalysed by } \\
\text { immobilized Kluyveromyces } \\
\text { lactis } \beta \text {-galactosidase }\end{array}$ & $\begin{array}{l}\text { coupled to pre-activated } \\
\text { nanotubes by reaction with a } \\
\text { carbodiimide }\end{array}$ & constant lactulose productivity of $1.29 \mathrm{~g} / \mathrm{dm}^{3}$ during $48 \mathrm{~h}$ & $(104)$ \\
\hline $\begin{array}{l}\text { Laccase-immobilized } \\
\text { microreactors applied for the } \\
\text { biotransformation of model } \\
\text { compounds }\end{array}$ & $\begin{array}{l}\text { covalently bound to the inner } \\
\text { surface of a microreactor by the } \\
\text { APTES/GA method }\end{array}$ & $\begin{array}{l}\text { an immobilization yield of } 72 \% \text { and enzyme activity of } \\
451 \mathrm{~mol} /\left(\mathrm{dm}^{3} \cdot \mathrm{min}\right) \text { was achieved }\end{array}$ & $(105)$ \\
\hline $\begin{array}{l}\text { NADH regeneration using } \\
\text { immobilized formate } \\
\text { dehydrogenase }\end{array}$ & $\begin{array}{l}\text { immobilized layer of formate } \\
\text { dehydrogenase between two } \\
\text { layers of chitosan }\end{array}$ & $\begin{array}{l}\text { immobilized FDH kept half of its enzymatic activity for } \\
\text { practically two weeks, and the polymeric matrix allowed } \\
\text { transfer of NAD } \text { Nith relatively high diffusion coefficient }^{+} \text {with }\end{array}$ & $(106)$ \\
\hline $\begin{array}{l}\text { Immobilized } \beta \text {-glucosidase in } \\
\text { a silica quartz capillary tube } \\
\text { applied for cellobiose digestion }\end{array}$ & $\begin{array}{l}\text { covalently bound to the inner } \\
\text { surface of a microreactor by the } \\
\text { APTES/GA method }\end{array}$ & $\begin{array}{l}\text { maximum conversion rate of soluble substrate cellobiose } \\
\text { digestion in the microreactor was } 76 \% \text { at } 50{ }^{\circ} \mathrm{C} \text { and } \\
\mathrm{pH}=4.8 \text { when the microreactor operated continuously } \\
\text { over } 10 \mathrm{~h} \text { at a flow rate of } 7 \mathrm{~mm}^{3} / \mathrm{min}\end{array}$ & $(107)$ \\
\hline
\end{tabular}

APTES=(3-aminopropyl)triethoxysilane, $\mathrm{GA}=$ glutaraldehyde, $\mathrm{FDH}=$ formate dehydrogenase

\section{Multi-enzyme reactions}

If working with one enzyme is not challenging enough, multi-enzyme cascade reactions provide an even greater challenge. To coordinate all optimal reaction conditions, like temperature, $\mathrm{pH}$, concentrations and fluid flow is an art in and of itself. If you combine prevention of inhibition, byproduct formation and parallel side reactions, then the successful implementation of these reactions becomes a little miracle. Gruber et al. (113) underline that a key advantage of multi-enzyme reactions performed in microreactors is the ability to perform in vitro biosynthetic reaction. This offers modular approaches to coupling enzyme reactions and may utilize metabolic reaction cascades performed naturally by cells and organs or create de novo pathways in order to achieve the production of new molecules. Microreactors provide a new paradigm for performing multistep biosynthetic reactions, but they are also a good platform for rapid evaluation of the effects of reaction conditions and different enzymes.

\section{GOING BIG - MODULAR SYSTEMS TOWARDS INDUSTRIAL APPLICATION}

For many years now microreactor technology has been reserved mainly for laboratory research where researchers are collecting information about how to transfer the process from batch to flow, about process optimization, production, kinetic measurements, separation, discovering new production routes, etc., all on the microscale. Slowly the interest is now shifting towards development of robust modular systems that include 
all production steps from initial substrate introduction into the process to clean product at the end of the process. Although this process seems simple in theory, in order to achieve these goals some technical obstacles need to be resolved, mainly scaling/numbering up. The first problem is the cost of microreactor chips since many of them, produced from traditional materials like glass, stainless steel, ceramic, etc. tend to be expensive. As a solution, application of microchips produced from polymers has been proposed (8). The second challenge is to ensure stabile flow through the system since pressure drop can cause instabilities. In order to resolve this problem, application of larger meso- or millireactor was proposed (91). This would also allow higher throughputs leading to production of larger amounts (even tonnes) of product per year. The following section of the paper offers more details about the obstacles. Nevertheless, despite all obstacles, at the moment several manufactures like Chemtrix B.V. or Corning offer commercial reactors for scale-up of single and multiphase flow chemistry (8). Unfortunately, most of them are traditionally reserved for reaction in chemistry and for production of pharmaceutics. As application of microreactors in biotechnology had a slow start in a laboratory in comparison to chemical reactions, the same effect was reflected on the development of modular systems. Now, they are slowly catching up in a race and up to now several processes have been tested (6), like the reaction of the DL-amino acid oxidase (114) or production of different flavours, like isoamyl acetate synthesis (115). Despite all promising results, there are still some bumpy roads ahead and obstacles to overcome before we jump to industrial production.

\section{OBSTACLES TO BE OVERCOME}

Biotechnology on a small scale is already present but many of the shown reactions are performed within reactor systems developed primarily for chemical reactions. There are still some obstacles to be overcome when talking about engineering of enzymatic microreactors. In her thesis Denčić (116) suggested several bottlenecks of using a microreactor for biocatalysis and other biotechnological reactions:

\section{Residence time distribution}

Short residence time is one of the main microreactor characteristics. Therefore, fast reactions should be preferably performed in microreactors. In order to bring out their reaction maximum, biocatalysts need to be very active and stable. This usually requires new biocatalyst development. Yet microreactors cannot be used to replace all traditional biotechnology processes performed in macrosystems (12). The solution proposed to this problem is a design of new microreactor systems that will allow longer residence times needed for the desired conversion rates (117).

\section{Catalyst lifetime}

In comparison to the chemical catalyst, enzymatic catalysts have short lifetime. Consequently, it is necessary to develop an efficient miniaturized flow system that can enable a long-term use of the biocatalyst. One way to go is to utilize microreactor advantages like better process control to enhance stability and activity $(20,117)$ and the other one is to use immobilization techniques that can prolong catalyst stability and lifetime. Additionally, immobilization allows the continuous reuse of enzymes and simplifies biocatalyst recycling and downstream processing $(78,118,119)$.

\section{Cascade catalysis/coupled enzyme-enzyme reactions}

When working with multiple enzymes, the biggest challenge is to adapt reaction conditions so all the enzymes can achieve their maximum potential. As a solution, the compartmentalisation of the microreactors in order to tailor each reaction individually has been proposed. Second challenge is overcoming the inhibition effect of reactants in the cascade (120), which despite all efforts still continues to remain a great challenge (Fig. 5) (113).

\section{Demanding process change from batch to flow}

Up to now, many processes have been well established in batch reactors and simply shifting them to flow biotechnology does not mean that the process will perform better or even be sustainable (121). Therefore, synergy of biotechnology and

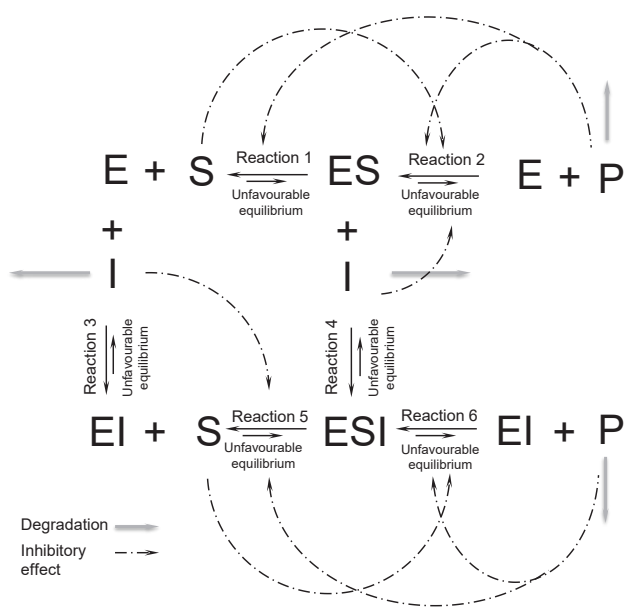

Fig. 5. Illustration of all potential sources of inhibition that can arise in an enzyme cascade ( $\mathrm{S}=$ substrate, $\mathrm{E}=$ enzyme, $\mathrm{P}=$ product, $\mathrm{I}=$ intermediate, $\mathrm{ES}=$ enzyme-substrate complex, $\mathrm{El}=$ enzyme-intermediate complex and $\mathrm{ESI}=$ enzyme-substrate-intermediate complex) 
engineering is necessary to overcome this obstacle, meaning that catalyst implementation and behaviour have to be seriously considered. Although the focus is usually laid 'only' on intensifying the transport phenomena to operate under intrinsic kinetics, there is also a large intensification potential in the specific design of flow processes.

\section{Handling the formation of solids}

When a reaction results in the precipitation of a solid (either a product or byproduct or enzyme dispersion), the problems with particles aggregating on the microchannel walls can cause blockages and a catastrophic failure (122-124). The same problem can occur when working with highly viscous solvents. Thus the development of solutions, such as microchannel surface modification and gas/liquid 'slug flow', are necessary to obtain the flow with solid precipitates.

\section{Scale-out}

As mentioned above, numbering-up or scale-out of microreactors is still a great challenge. Connecting thousands of units to achieve the industrial scale production rates $(\mathrm{kg} / \mathrm{h}$ or $\mathrm{t} / \mathrm{h})$, a complex control and management systems are needed to ensure optimal operating conditions in every single microreactor (111). On the other hand, the conventional scale-up (increasing the microchannel size) is not an option if it gets close to macroscale since their mass and heat efficiency is questionable. For now, a proposed solution is to work on the milli- $(125,126)$ or meso- $(6,8,27,36,41,44,76,92,127)$ scale which ensure good mass and heat efficiency and a satisfying production capacity.

Some other issues are usually connected with high fabrication costs, low throughput, incompatibility with solids and the omission of cost reduction by scale-up effects which lead to still poor industrial acceptance $(12,128)$. Likewise, the supporting equipment required for the microreactor function can be expensive. The example is low pulse or pulseless pumps needed to ensure stable flow in a microreactor and in most cases they are the most expensive parts of the microreactor set-up. Analytics represents another problem. A very long time period is required to obtain the amount of samples sufficient for a majority of conventional analyses if off-line analytics is used. It all results in many efforts invested in the development of effective and robust on-line analytical techniques for microdevices.

\section{CONCLUSIONS}

In keeping with the developmental stages of chemical microreactors, and having in mind that microreactors in biotechnology are slowly going through the very same stages, in the near future it can be expected that the new microreactor-based process design patents will become available. With the development of novel supports for enzyme immobilization, newly engineered enzymes and microreactor devices, many biotransformation processes will benefit from this new approach. One of the key products of the microreactor technology will also be information. The information about reaction, products, process, etc. will become more available in order to overcome the obstacles and the challenges in the production. Finally, all of this will lead to a more sustainable, greener and compact production in biotechnology.

\section{REFERENCES}

1. Hessel V, Tibhe J, Noël T, Wang Q. Biotechnical micro-flow processing at the EDGE - Lessons to be learnt for a young discipline. Chem Biochem Eng Q. 2014;28(2):167-88. https://doi.org/10.15255/CABEQ.2014.1939

2. Dencic I, Hessel V, de Croon MHJM, Meuldijk J, van der Doelen CWJ, Koch K. Recent changes in patenting behavior in microprocess technology and its possible use for gas-liquid reactions and the oxidation of glucose. ChemSusChem. 2012;5(2):232-45.

https://doi.org/10.1002/cssc.201100389

3. Hessel V, Knobloch C, Löwe H. Review on patents in microreactor and micro process engineering. Recent Pat Chem Eng. 2008;1(1):1-16.

https://doi.org/10.2174/2211334710801010001

4. Whitesides G. Microfluidics: Where from here? Kidlington, UK: The Kidlington Centre; 2018. Available from: http:// blog.globalengage.co.uk/microfluidics-george-whitesides-presentation?inf_contact_key=650f2f38e03b1d88ff000441f6b9d995bd7d3b964b73ea9b2bfc701948f2 80e2\&hsCtaTracking=b091b68c-d088-4974-9b1d-e74f158b1663\%7Ca41 be247-0b07-4fa5-9a9f-0321a6203293.

5. Ehrfeld W, Hessel V, Löwe H. Microreactors: New technology for modern chemistry. Weinheim, Germany: Wiley-VCH; 2005. pp. 1-69.

6. Žnidaršič-Plazl P. Biotransformations in microflow systems: Bridging the gap between academia and industry. J Flow Chem. 2017;7(3-4):111-7. https://doi.org/10.1556/1846.2017.00021

7. European patent office. Munich, Germany. Available from: https://www.epo.org/searching-for-patents/technical/espacenet.html\#tab-1.

8. Jensen KF. Flow chemistry - Microreaction technology comes of age. AlChE J. 2017;63(3):858-69.

https://doi.org/10.1002/aic.15642

9. Elvira KS, Casadevall i Solvas X, Wootton RCR, deMello AJ. The past, present and potential for microfluidic reactor technology in chemical synthesis. Nat Chem. 2013;5:905-15. https://doi.org/10.1038/nchem.1753

10. Yao X, Zhang Y, Du L, Liu J, Yao J. Review of the application of microreactors. Renew Sust Energ Rev. 2015;47:519-39. https://doi.org/10.1016/j.rser.2015.03.078

11. McCreedy T. Fabrication techniques and materials commonly used for the production of microreactors and micro total analytical systems. Trends Anal Chem. 2000;19(6):396-401. https://doi.org/10.1016/S0165-9936(99)00176-4 
12. Šalić $A$, Tušek A, Zelić B. Application of microreactors in medicine and biomedicine. J Appl Biomed. 2012;10(3):137-53. https://doi.org/10.2478/v10136-012-0011-1

13. Choi S, Park JK. Two-step photolithography to fabricate multilevel microchannels. Biomicrofluidics. 2010;4(4):046503. https://doi.org/10.1063/1.3517230

14. Jia YF, Jiang JH, Ma XD, Li Y, Huang HM, Cai KB, et al. PDMS microchannel fabrication technique based on microwiremolding. Chin Sci Bull. 2008;53(24):3928-36. https://doi.org/10.1007/s11434-008-0528-6

15. Nguyen NT, Wu Z. Micromixers - A review. J Micromech Microeng. $2005 ; 15(2): \mathrm{R} 1-16$. https://doi.org/10.1088/0960-1317/15/2/R01

16. Hessel V, Löwe H, Schönfeld F. Micromixers - A review on passive and active mixing principles. Chem Eng Sci. 2005;60 (8-9):2479-501.

https://doi.org/10.1016/j.ces.2004.11.033

17. Wen Z, Yu X, Tu ST, Yan J, Dahlquist E. Intensification of biodiesel synthesis using zigzag micro-channel reactors. Bioresour Technol. 2009;100(12):3054-60.

https://doi.org/10.1016/j.biortech.2009.01.022

18. Yoshida J, Kim H, Nagaki A. Green and sustainable chemical synthesis using flow microreactors. ChemSusChem. 2011; 4(3):331-40. https://doi.org/10.1002/cssc.201000271

19. Swarts JW, Kolfschoten RC, Jansen MCAA, Janssen AEM, Boom RM. Effect of diffusion on enzyme activity in a microreactor. Chem Eng J. 2010;162(1):301-6. https://doi.org/10.1016/j.cej.2010.04.040

20. Urban PL, Goodall DM, Bruce NC. Enzymatic microreactors in chemical analysis and kinetic studies. Biotechnol Adv. 2006;24(1):42-57.

https://doi.org/10.1016/j.biotechadv.2005.06.001

21. Vasić-Rački $Đ$, Kragl U, Liese A. Benefits of enzyme kinetics modelling. Chem Biochem Eng Q. 2003;17(1):7-18.

22. Tadepalli S, Qian D, Lawal A. Comparison of performance of microreactor and semi-batch reactor for catalytic hydrogenation of o-nitroanisole. Catal Today. 2007;125(1-2):64-73. https://doi.org/10.1016/j.cattod.2007.01.076

23. Tušek A, Šalić A, Kurtanjek Ž, Zelić B. Modeling and kinetic parameter estimation of alcohol dehydrogenase-catalyzed hexanol oxidation in a microreactor. Eng Life Sci. 2012; 12(1):49-56.

https://doi.org/10.1002/elsc.201100020

24. Pohar A, Plazl I. Process intensification through microreactor application. Chem Biochem Eng Q. 2009;23(4):537-44.

25. Dittrich PS, Manz A. Lab-on-a-chip: Microfluidics in drug discovery. Nat Rev Drug Discov. 2006;5:210-8.

https://doi.org/10.1038/nrd1985

26. Goodell JR, McMullen JP, Zaborenko N, Maloney JR, Ho CX, Jensen KF, et al. Development of an automated microfluidic reaction platform for multidimensional screening: Reaction discovery employing bicyclo[3.2.1] octanoid scaffolds. J Org Chem. 2009;74(16):6169-80.

https://doi.org/10.1021/jo901073v

27. Zaborenko N, Bedore MW, Jamison TF, Jensen KF. Kinetic and scale-up investigations of epoxide aminolysis in microreactors at high temperatures and pressures. Org Process Res Dev. 2010;15(1):131-9.

https://doi.org/10.1021/op100252m

28. Pieber B, Kappe CO. Direct aerobic oxidation of 2-benzylpyridines in a gas-liquid continuous-flow regime using propylene carbonate as a solvent. Green Chem. 2013;15(2):320-4. https://doi.org/10.1039/c2gc36896j

29. Lee CC, Sui G, Elizarov A, Shu CJ, Shin YS, Dooley AN, et al. Multistep synthesis of a radiolabeled imaging probe using integrated microfluidics. Science. 2005;310(5755):1793-6. https://doi.org/10.1126/science.1118919

30. Baek J, Allen PM, Bawendi MG, Jensen KF. Investigation of indium phosphide nanocrystal synthesis using a high-temperature and high-pressure continuous flow microreactor. Angew Chem Int Ed. 2011;50(3):627-30. https://doi.org/10.1002/anie.201006412

31. Pelleter J, Renaud F. Facile, fast and safe process development of nitration and bromination reactions using continuous flow reactors. Org Process Res Dev. 2009;13(4):698-705. https://doi.org/10.1021/op8002695

32. Watts $P$, Haswell SJ. Continuous flow reactors for drug discovery. Drug Discov Today. 2003;8(13):586-93. https://doi.org/10.1016/S1359-6446(03)02732-6

33. Asai T, Takata A, Ushiogi Y, linuma Y, Nagaki A, Yoshida J. Switching reaction pathways of benzo[b]thiophen-3-yllithium and benzo[b]furan-3-yllithium based on high-resolution residence-time and temperature control in a flow microreactor. Chem Lett. 2011;40(4):393-5.

https://doi.org/10.1246/cl.2011.393

34. Haswell SJ, O'Sullivan B, Styring P. Kumada. Corriu reactions in a pressure-driven microflow reactor. Lab Chip. 2001; 1(2):164-6. https://doi.org/10.1039/b104035A

35. Illg T, Hessel V, Löb P, Schouten JC. Continuous synthesis of tert-butyl peroxypivalate using a single-channel microreactor equipped with orifices as emulsification units. ChemSusChem. 2011;4(3):392-8.

https://doi.org/10.1002/cssc.201000368

36. Hartman RL, McMullen JP, Jensen KF. Deciding whether to go with the flow: Evaluating the merits of flow reactors for synthesis. Angew Chem Int Ed. 2011;50(33):7502-19.

https://doi.org/10.1002/anie.201004637

37. Schenk R, Hessel V, Hofmann C, Kiss J, Löwe H, Ziogas A. Numbering-up of microdevices: A first liquid-flow splitting unit. Chem Eng J. 2004;101(1-3):421-9. https://doi.org/10.1016/j.cej.2003.11.034 
38. Löwe H, Hessel V, Mueller A. Microreactors. Prospects already achieved and possible misuse. Pure Appl Chem. 2002; 74(12):2271-6.

https://doi.org/10.1351/pac200274122271

39. Carpentier JC. Process intensification by miniaturisation. Chem Eng Technol. 2005;28(3):255-8. https://doi.org/10.1002/ceat.200407026

40. Yoshida J. Flash chemistry: Fast organic synthesis in microsystems. Chichester, UK: John Wiley \& Sons, Ltd; 2008. https://doi.org/10.1002/9780470723425

41. Kockmann N, Gottsponer M, Zimmermann B, Roberge DM. Enabling continuous-flow chemistry in microstructured devices for pharmaceutical and fine-chemical production. Chem Eur J. 2008;14(25):7470-7. https://doi.org/10.1002/chem.200800707

42. Asanomi Y, Yamaguchi H, Miyazaki M, Maeda H. Enzyme-immobilized microfluidic process reactors. Molecules. 2011; 16(7):6041-59.

https://doi.org/10.3390/molecules16076041

43. Miyazaki M, Maeda H. Microchannel enzyme reactors and their applications for processing. Trends Biotechnol. 2006; 24(10):463-70.

https://doi.org/10.1016/j.tibtech.2006.08.002

44. Wohlgemuth R, Plazl I, Žnidaršič-Plazl P, Gernaey KV, Woodley JM. Microscale technology and biocatalytic processes: Opportunities and challenges for synthesis. Trends Biotechnol. 2015;33(5):302-14.

https://doi.org/10.1016/j.tibtech.2015.02.010

45. Tamborini L, Fernandes P, Paradisi F, Molinari F. Flow bioreactors as complementary tools for biocatalytic process intensification. Trends Biotechnol. 2018;36(1):73-88.

https://doi.org/10.1016/j.tibtech.2017.09.005

46. Posthuma-Trumpie GA, Venema K, van Berkel WJH, Korf J. A low perfusion rate microreactor for continuous monitoring of enzyme characteristics: Application to glucose oxidase. Anal Bioanal Chem. 2007;389(6):2029-33. https://doi.org/10.1007/s00216-007-1596-1

47. Laurenti E, dos Santos Vianna Jr A. Enzymatic microreactors in biocatalysis: History, features, and future perspectives. Biocatalysis. 2015;1(1):148-65.

https://doi.org/10.1515/boca-2015-0008

48. Jurinjak Tušek A, Tišma M, Bregović V, Ptičar A, Kurtanjek Ž, Zelić B. Enhancement of phenolic compounds oxidation using laccase from Trametes versicolor in a microreactor. Biotechnol Bioprocess Eng. 2013;18(14):686-96. https://doi.org/10.1007/s12257-012-0688-8

49. Žnidaršič-Plazl P. Enzymatic microreactors utilizing non-aqueous media. Chim Oggi. 2014;32(1):54-61.

50. Bolivar JM, Nidetzky B. Multiphase biotransformations in microstructured reactors: Opportunities for biocatalytic process intensification and smart flow processing. Green Process Synth. 2013;2(6):541-59.

https://doi.org/10.1515/gps-2013-0091
51. Šalić $A$, Tušek $A$, Kurtanjek Ž, Zelić B. Biotransformation in a microreactor: New method for production of hexanal. Biotechnol Bioprocess Eng. 2011;16(3):495-504.

https://doi.org/10.1007/s12257-010-0381-8

52. Šalić $A$, Zelić $B$. ADH catalysed hexanol oxidation with fully integrated NADH regeneration performed in microreactors connected in series. RSC Adv. 2014;4(79):41714-21.

https://doi.org/10.1039/C4RA05421K

53. Vrsalović Presečki A, Vasić-Rački Đ. Mathematical modelling of the dehydrogenase catalyzed hexanol oxidation with coenzyme regeneration by NADH oxidase. Process Biochem. 2009;44(1):54-61.

https://doi.org/10.1016/j.procbio.2008.09.007

54. Harries N, Burns JR, Barrow DA, Ramshaw CA. A numerical model for segmented flow in a microreactor. Int J Heat Mass Transfer. 2003;46(17):3313-22.

https://doi.org/10.1016/S0017-9310(03)00120-0

55. Pohar A, Plazl I, Žnidaršič-Plazl P. Lipase-catalyzed synthesis of isoamyl acetate in an ionic liquid/n-heptane two-phase system at the microreactor scale. Lab Chip. 2009;9(23): 3385-90.

https://doi.org/10.1039/b915151f

56. Tišma M, Zelić B, Vasić-Rački Đ, Žnidaršič-Plazl P, Plazl I. Modelling of laccase-catalyzed L-DOPA oxidation in a microreactor. Chem Eng J. 2009;149(1-3):383-8.

https://doi.org/10.1016/j.cej.2009.01.025

57. Žnidaršič-Plazl P, Plazl I. Modelling and experimental studies on lipase-catalyzed isoamyl acetate synthesis in a microreactor. Process Biochem. 2009;44(10):1115-21. https://doi.org/10.1016/j.procbio.2009.06.003

58. Marques MPC, Fernandes P, Cabral JMS, Žnidaršič-Plazl P, Plazl I. On the feasibility of the in situ steroid biotransformation and product recovery in microchannels. Chem Eng J. 2010;160(2):708-14.

https://doi.org/10.1016/j.cej.2010.03.056

59. Tudorache M, Mahalu D, Teodorescu C, Stan R, Bala C, Parvulescu VI. Biocatalytic microreactor incorporating HRP anchored on micro-/nano-lithographic patterns for flow oxidation of phenols. J Mol Catal B Enzym. 2011;69(3-4):133-9. https://doi.org/10.1016/j.molcatb.2011.01.007

60. Čech J, Schrott W, Slouka Z, Přibyl M, Brož M, Kuncová G, Šnita D. Enzyme hydrolysis of soybean oil in a slug flow microsystem. Biochem Eng J. 2012;67:194-202.

https://doi.org/10.1016/j.bej.2012.06.015

61. O'Sullivan B, Al-Bahrani H, Lawrence J, Campos M, Cázares A, Baganz F, et al. Modular microfluidic reactor and inline filtration system for the biocatalytic synthesis of chiral metabolites. J Mol Catal B Enzym. 2012;77:1-8.

https://doi.org/10.1016/j.molcatb.2011.12.010

62. Šalić A, Ivanković M, Ferk E, Stuparić M, Tišma M, Zelić B. Development of $\mathrm{NAD}^{+}$regeneration process in microreactors of different materials. Chem Eng Trans. 2012;27;193-8.

https://doi.org/10.3303/CET1227033 
63. Sudar M, Findrik Z, Vasić-Rački $Đ$, Clapés P, Lozano C. Aldol addition of dihydroxyacetone to $\mathrm{N}$-Cbz-3-aminopropanal catalyzed by two aldolase variants in microreactors. Enzyme Microb Technol. 2013;53(1):38-45.

https://doi.org/10.1016/j.enzmictec.2013.03.013

64. Valinger D, Vrsalović Presečki A, Kurtanjek Ž, Pohl M, Findrik Blažević Z, Vasić-Rački Đ. Continuous enzymatic carboligation of benzaldehyde and acetaldehyde in an enzyme ultrafiltration membrane reactor and laminar flow microreactors. J Mol Catal B Enzym. 2014;102:132-7.

https://doi.org/10.1016/j.molcatb.2014.02.003

65. Koch K, van den Berg RJF, Nieuwland PJ, Wijtmans R, Wubbolts MG, Schoemaker HE, et al. Enzymatic synthesis of optically pure cyanohydrins in microchannels using a crude cell lysate. Chem Eng J. 2008;135(Suppl. 1):S89-92.

https://doi.org/10.1016/j.cej.2007.07.013

66. Matosevic S, Szita N, Baganz F. Fundamentals and applications of immobilised microfluidic enzymatic reactor. J Chem Technol Biotechnol. 2011;86(3):325-34.

https://doi.org/10.1002/jctb.2564

67. Nikolova P, Ward OP. Whole cell yeast biotransformation in two-phase system: Effect of solvent on product formation and cell structure. J Ind Microbiol. 1992;10(3-4):169-77.

https://doi.org/10.1007/BF01569762

68. Chen R. Permeability issues in whole-cell bioprocesses and cellular membrane engineering. Appl Microbiol Biotechnol. 2007;74(4):730-8.

https://doi.org/10.1007/s00253-006-0811-x

69. Kaur G, Panesar PS, Bera MB, Kumar H. Hydrolysis of whey lactose using CTAB-permeabilized yeast cells. Bioprocess Biosyst Eng. 2009;32(1):63-7. https://doi.org/10.1007/s00449-008-0221-9

70. Šalić $A$, Faletar $P$, Zelić $B$. NAD ${ }^{+}$regeneration in a microreactor using permeabilized baker's yeast cells. Biochem Eng J. 2013;77:88-96.

https://doi.org/10.1016/j.bej.2013.05.007

71. Šalić A, Pindrić K, Zelić B. Bioproduction of food additives hexanal and hexanoic acid in a microreactor. Appl Biochem Biotechnol. 2013;171(8):2273-84. https://doi.org/10.1007/s12010-013-0495-5

72. Maruyama T, Uchida J, Ohkawa T, Futami T, Katayama K, Nishizawa K, et al. Enzymatic degradation of p-chlorophenol in a two-phase flow microchannel system. Lab Chip. 2003;3(4):308-12.

https://doi.org/10.1039/b309982b

73. Pandya PH, Jasra RV, Newalkar BL, Bhatt PN. Studies on the activity and stability of immobilized a-amylase in ordered mesoporous silicas. Micropor Mesopor Mat. 2005;77(1):67-77. https://doi.org/10.1016/j.micromeso.2004.08.018

74. Stojkovič G, Plazl I, Žnidaršič-Plazl P. L-Malic acid production within a microreactor with surface immobilised fumarase.
Microfluid Nanofluidics. 2011;10(3):627-35.

https://doi.org/10.1007/s10404-010-0696-y

75. Sheldon RA, Schoevaart R, van Langen LM. Cross-linked enzyme aggregates (CLEAs): A novel and versatile method for enzyme immobilization (a review). Biocatal Biotransform. 2005;23(3-4):141-7.

https://doi.org/10.1080/10242420500183378

76. Bolivar M, Wiesbauer J, Nidetzky B. Biotransformations in microstructured reactors: More than flowing with the stream? Trends Biotechnol. 2011;29(7)333-42.

https://doi.org/10.1016/j.tibtech.2011.03.005

77. Wong LS, Khan F, Micklefield J. Selective covalent protein immobilization: Strategies and applications. Chem Rev. 2009;109(9):4025-53.

https://doi.org/10.1021/cr8004668

78. Mateo C, Palomo JM, Fernandez-Lorente G, Guisan JM, Fernandez-Lafuente R. Improvement of enzyme activity, stability and selectivity via immobilization techniques. Enzyme Microb Technol. 2007;40(6):1451-63.

https://doi.org/10.1016/j.enzmictec.2007.01.018

79. Meller K, Szumski M, Buszewski B. Microfluidic reactors with immobilized enzymes - Characterization, dividing, perspectives. Sens Actuators B Chem. 2017;244:84-106. https://doi.org/10.1016/j.snb.2016.12.021

80. Bolivar JM, Luley-Goedl C, Leitner E, Sawangwan T, Nidetzky B. Production of glucosyl glycerol by immobilized sucrose phosphorylase: Options for enzyme fixation on a solid support and application in microscale flow format. J Biotechnol. 2017;257:131-8. https://doi.org/10.1016/j.jbiotec.2017.01.019

81. Miložič N, Lubej M, Lakner M, Žnidaršič-Plazl P, Plazl I. Theoretical and experimental study of enzyme kinetics in a microreactor system with surface-immobilized biocatalyst. Chem Eng J. 2017;313(1):374-81. https://doi.org/10.1016/j.cej.2016.12.030

82. Miložič N, Stojkovič G, Vogel A, Bouwes D, Žnidaršič-Plazl P. Development of microreactors with surface-immobilized biocatalysts for transamination. New Biotechnol. 2018;47: 18-24. https://doi.org/10.1016/j.nbt.2018.05.004

83. Valikhani D, Bolivar JM, Pfeiffer M, Nidetzky B. Multivalency effects on the immobilization of sucrose phosphorylase in flow microchannels and their use in the development of a high-performance biocatalytic microreactor. ChemCatChem. 2016;9(1):161-6. https://doi.org/10.1002/cctc.201601019

84. Bolivar JM, Nidetzky B. Smart enzyme immobilization in microstructured reactors. Chim Oggi. 2013;31(3):50-4.

85. Block H, Maertens B, Spriestersbach A, Brinker N, Kubicek J, Fabis $\mathrm{R}$, et al. Immobilized-metal affinity chromatography (IMAC): A review. Methods Enzymol. 2009; 463:439-73. https://doi.org/10.1016/S0076-6879(09)63027-5 
86. Cohen SA, Michaud DP. Synthesis of a fluorescent derivatizing reagent, 6-aminoquinolyl-N-hydroxysuccinimidyl carbamate, and its application for the analysis of hydrolysate amino acids via high-performance liquid chromatography. Anal Biochem. 1993;211(2):279-87.

https://doi.org/10.1006/abio.1993.1270

87. Halim AA, Szita N, Baganz F. Characterization and multi-step transketolase- $\omega$-transaminase bioconversions in an immobilized enzyme microreactor (IEMR) with packed tube. J Biotechnol. 2013;168(4):567-75.

https://doi.org/10.1016/j.jbiotec.2013.09.001

88. Kulsharova G, Dimov N, Marques MPC, Szita N, Baganz F. Simplified immobilisation method for histidine-tagged enzymes in poly(methyl methacrylate) microfluidic devices. New Biotehnol. 2018;47:31-8. https://doi.org/10.1016/j.nbt.2017.12.004

89. Junior II, Flores MC, Sutili KS, Leite SGF, Miranda LSM, Leal ICR, de Souza ROMA. Lipase-catalyzed monostearin synthesis under continuous flow conditions. Org Process Res Dev. 2012;16(5):1098-101. https://doi.org/10.1021/op200132y

90. Cvjetko M, Vorkapić-Furač J, Žnidaršič-Plazl P. Isoamyl acetate synthesis in imidazolium-based ionic liquids using packed bed enzyme microreactor. Process Biochem. 2001; 47(9):1344-50.

https://doi.org/10.1016/j.procbio.2012.04.028

91. Bajić M, Plazl I, Stloukal R, Žnidaršič-Plazl P. Development of a miniaturized packed bed reactor with $\omega$-transaminase immobilized in LentiKats ${ }^{\circledR}$. Process Biochem. 2017;52:63-72. https://doi.org/10.1016/j.procbio.2016.09.021

92. Strniša F, Bajić M, Panjan P, Plazl I, Sesay AM, Žnidaršič-Plazl P. Characterization of an enzymatic packed-bed microreactor: Experiments and modeling. Chem Eng J. 2018;350:541-50. https://doi.org/10.1016/j.cej.2018.05.028

93. Planchestainer M, Contente ML, Cassidy J, Molinari F, Tamborini L, Paradisi F. Continuous flow biocatalysis: Production and inline purification of amines by immobilised transaminase from Halomonas elongata. Green Chem. 2017; 19(2):372-5.

https://doi.org/10.1039/C6GC01780K

94. Duguet E, Vasseur S, Mornet S, Devoisselle JM. Magnetic nanoparticles and their applications in medicine. Nanomed. 2006;1(2):157-68.

https://doi.org/10.2217/17435889.1.2.157

95. McCarthy JR, Kelly KA, Sun EY, Weissleder R. Targeted delivery of multifunctional magnetic nanoparticles. Nanomed. 2007;2(2):153-67. https://doi.org/10.2217/17435889.2.2.153

96. Yang Y, Bai YX, Li YF, Lei L, Chui YJ, Xia CG. Characterization of Candida rugosa lipase immobilized onto magnetic microspheres with hydrophilicity. Process Biochem. 2008; 43(11):1179-85.

https://doi.org/10.1016/j.procbio.2008.05.019
97. Netto CGCM, Toma HE, Andraden LH. Superparamagnetic nanoparticles as versatile carriers and supporting materials for enzymes. J Mol Catal B Enzym. 2013;85-86:71-92. https://doi.org/10.1016/j.molcatb.2012.08.010

98. Kang SC, Jo YJ, Bak JP, Kim KC, Kim YS. Evaluation for protein binding affinity of maghemite and magnetite nanoparticles. Nanosci Nanotechno. 2007;7(11):3706-8.

https://doi.org/10.1166/jnn.2007.022

99. Šalić A, Pindrić K, Hojnik Podrepšek G, Leitgeb M, Zelić B. $\mathrm{NADH}$ oxidation in a microreactor catalyzed by ADH immobilized on $\mathrm{Y}^{-} \mathrm{Fe}_{2} \mathrm{O}_{3}$ nanoparticles. Green Process Synth. 2013;2(6),569-79.

https://doi.org/10.1515/gps-2013-0084

100. Schwarz A, Thomsen MS, Nidetzky B. Enzymatic synthesis of $\beta$-glucosylglycerol using a continuous-flow microreactor containing thermostable $\beta$-glycoside hydrolase CelB immobilized on coated microchannel walls. Biotechnol Bioeng. 2009;103(5):865-72.

https://doi.org/10.1002/bit.22317

101. Mugo SM, Ayton K. Lipase immobilized microstructured fiber based flow-through microreactor for facile lipid transformations. J Mol Catal B Enzym. 2010;67(3-4):202-7.

https://doi.org/10.1016/j.molcatb.2010.08.006

102. Machsun AL, Gozan M, Nasikin M, Setyahadi S, Yoo YJ. Membrane microreactor in biocatalytic transesterification of triolein for biodiesel production. Biotechnol Bioprocess Eng. 2010;15(6):911-6. https://doi.org/10.1007/s12257-010-0151-7

103. Stojkovič G, Žnidaršič-Plazl P. Continuous synthesis of L-malic acid using whole-cell microreactor. Process Biochem. 2012;47(7):1102-7. https://doi.org/10.1016/j.procbio.2012.03.023

104. Song YS, Shin HY, Lee JY, Park C, Kim SW. $\beta$-Galactosidase-immobilised microreactor fabricated using a novel technique for enzyme immobilisation and its application for continuous synthesis of lactulose. Food Chem. 2012; 133(3):611-7.

https://doi.org/10.1016/j.foodchem.2012.01.096

105. Lloret L, Eibes G, Moreira MT, Feijoo G, Lema JM, Miyazaki M. Improving the catalytic performance of laccase using novel continuous-flow microreactor. Chem Eng J. 2013;223:497-506. https://doi.org/10.1016/j.cej.2013.03.018

106. Roche J, Groenen-Serrano K, Reynes O, Chauvet F, Tzedakis T. NADH regenerated using immobilized FDH in a continuously supplied reactor - Application to L-lactate synthesis. Chem Eng J. 2014;239:216-25. https://doi.org/10.1016/j.cej.2013.10.096

107. Wei C, Zhou Y, Zhuang W, Li G, Jiang M, Zhang H. Improving the performance of immobilized $\beta$-glucosidase using a microreactor. J Biosci Bioeng. 2018;125(4):377-84.

https://doi.org/10.1016/j.jbiosc.2017.09.011 
108. Yamaguchi H, Honda T, Miyazaki M. Application of enzyme-immobilization technique for microflow reactor. J Flow Chem. 2016;6(1):13-7.

https://doi.org/10.1556/1846.2015.00039

109. Thomsen MS, Nidetzky B. Coated-wall microreactor for continuous biocatalytic transformations using immobilized enzymes. Biotechnol J. 2009;4(1):98-107.

https://doi.org/10.1002/biot.200800051

110. Safdar M, Sproß J, Jänis J. Microscale immobilized enzyme reactors in proteomics: Latest developments. J Chromatogr A. 2014;1324:1-10.

https://doi.org/10.1016/j.chroma.2013.11.045

111. Hajba L, Guttman A. Continuous-flow biochemical reactors: Biocatalysis, bioconversion, and bioanalytical applications utilizing immobilized microfluidic enzyme reactors, J Flow Chem. 2016;6(1):8-12.

https://doi.org/10.1556/1846.2015.00028

112. Kecskemeti A, Gaspar A. Particle-based immobilized enzymatic reactors in microfluidic chips. Talanta. 2018;180:211-28.

https://doi.org/10.1016/j.talanta.2017.12.043

113. Gruber P, Marques MPC, O'Sullivan B, Baganz F, Wohlgemuth R, Szita N. Conscious coupling: The challenges and opportunities of cascading enzymatic microreactors. Biotechnol J. 2017;12(7):1700030.

https://doi.org/10.1002/biot.201700030

114. Gasparini G, Archer I, Jones E, Ashe R. Scaling up biocatalysis reactions in flow reactors. Org Process Res Dev. 2012;16(5):1013-6.

https://doi.org/10.1021/op2003612

115. Novak U, Lavric D, Žnidaršič-Plazl P. Continuous lipase B-catalyzed isoamyl acetate synthesis in a two-liquid phase system using Corning ${ }^{\circledR} \mathrm{AFR}^{\mathrm{TM}}$ module coupled with a membrane separator enabling biocatalyst recycle. J Flow Chem. 2016;6(1):33-8.

https://doi.org/10.1556/1846.2015.00038

116. Denčić I. Ex-ante process design intensification and cost benefits enabled by smart supported chemical and enzymatic catalysis [PhDThesis]. Eindhoven, The Netherlands: TU Eindhoven; 2014 (in English).

117. Fernandes P. Miniaturization in biocatalysis. Int J Mol Sci. 2010;11(3):858-79.

https://doi.org/10.3390/ijms11030858
118. Cao L. Carrier-bound immobilized enzymes: Principles, applications and design. Weinheim, Germany: Wiley-VCH Verlag GmbH \& Co. KGaA; 2005.

119. Liese A, Hilterhaus L. Evaluation of immobilized enzymes for industrial applications. Chem Soc Rev. 2013;42(15): 6236-49. https://doi.org/10.1039/c3cs35511j

120. Ardao I, Hwang ET, Zeng AP. In vitro multienzymatic reaction systems for biosynthesis. In: Zeng AP, editor. Fundamentals and application of new bioproduction systems. Berlin, Germany: Springer; 2013. pp. 153-84. https://doi.org/10.1002/cssc.201100445

121. Kralisch D, Streckmann I, Ott D, Krtschil U, Santacesaria E, Di Serio M, et al. Transfer of the epoxidation of soybean oil from batch to flow chemistry guided by cost and environmental issue. ChemSusChem. 2012;5(2):300-11. https://doi.org/10.1002/cssc.201100445

122. Khan SA, Günther A, Schmidt MA, Jensen KF. Microfluidic synthesis of colloidal silica. Langmuir. 2004;20(20):8604-11. https://doi.org/10.1021/la0499012

123. Knowles JP, Elliott LD, Booker-Milburn KI. Flow photochemistry: Old light through new windows. Beilstein J Org Chem. 2012;8:2025-52. https://doi.org/10.3762/bjoc.8.229

124. Poe SL, Cummings MA, Haaf MP, McQuade DT. Solving the clogging problem: Precipitate-forming reactions in flow. Angew Chem Int Ed. 2006;45(10):1544-8.

https://doi.org/10.1002/anie.200503925

125. Woitalka A, Kuhn S, Jensen KF. Scalability of mass transfer in liquid-liquid flow. Chem Eng Sci. 2014;116:1-8. https://doi.org/10.1016/j.ces.2014.04.036

126. Nieves-Remacha MJ, Kulkarni AA, Jensen KF. Hydrodynamics of liquid-liquid dispersion in an advanced-flow reactor. Ind Eng Chem Res. 2012;51(50):16251-62. https://doi.org/10.1021/ie301821k

127. Prašnikar A, UrbićT, Plazl I. Microscale technology and biocatalytic processes (Part 1): How to minimize the gap between research and industry. Chim Oggi. 2017;35:12-4.

128. Westermann T. Flow-through membrane microreactor for intensified heterogeneous catalysis [PhDThesis]. Aachen, Germany: Technisches Hochshule; 2009 (in English). 